\title{
STUDY OF CUCUMBER MOSAIC VIRUS GENE EXPRESSION IN CAPSICUM ANNUUM
}

\section{Nur Hafizah Azizan, Zulkifli Ahmad Zainal Abidin, Ing Chia Phang}

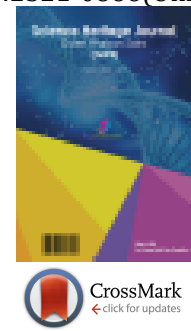

Department of Biotechnology, Kulliyyah of Science, International Islamic University Malaysia Jalan Sultan Ahmad Shah, Bandar Indera Mahkota, 25200, Kuantan, Pahang, Malaysia.

*Corresponding author E-mail: fizahazizan@iium.edu.my.

This is an open access article distributed under the Creative Commons Attribution License, which permits unrestricted use, distribution, and reproduction in any medium, provided the original work is properly cited

\section{ARTICLE DETAILS}

\section{Article History:}

Received 3 July 2017

Accepted 3 October 2017

Available online 6 December 2017

Keywords:

Capsicum annum, cDNA, Cucumber mosaic virus, RT-PCR..

\section{ABSTRACT}

Cucumber mosaic virus (CMV) is a plant pathogenic virus in the genus Cucumovirus, family Bromoviridae. It has the potential and reputation of having the widest host range of any known plant virus including monocotyledons and dicotyledons, herbaceous plants, shrubs and trees. CMV is one of the major diseases in Capsicum annum (chilli). Chilli plant samples exhibiting virus-like disease symptoms were collected from Taman Pertanian Indera Mahkota (location 1) and Greenhouse 12 of Horticulture Research Centre, Serdang (location 2). Viral disease was detected based on symptoms like mosaic-mottling, yellow ringspots and cholorotic that appeared on the leaves. The isolation of total RNA was done by using Vivantis GF-1 total RNA extraction kit. RT-PCR technique was used to detect the presence of virus disease symptoms gene in chillies. Identification of causal agents was based on cDNA amplified product size, using virus-specific oligonucleotides. Actin was used as the internal PCR control. The product size of the DNA fragment was $315 \mathrm{bp}$. From RT-PCR, the expression of CMV can be detected in chilli plants that exhibited the virus-like disease symptoms. This research revealed that some of the chilli plants at the Taman Pertanian Indera Mahkota and Greenhouse 12 of Horticulture Research Centre have been affected by this viral disease.

\section{INTRODUCTION}

Capsicum annum or chilli has been domesticated historically, for 7,000 years. Therefore, it has been considered as ancient crops [1]. In 1542, chilli was then adopted by the local people, and it has been recorded as native to the India by a German botanist, Leonhard Fuchs. Capsicum annum, which originated from Mexico contains both, the large-fruited bell peppers and small pungent types, is the most widely cultivated species. It has become the predominant chilli globally, partly because it was the first chilli discovered by Columbus and introduced to the rest of the world. More than 450 ago Portuguese and Spanish traders introduced this fruit to the Asian continent. Today, chilli has been used to prepare local cuisine such as Malaysian or Indonesian sambal, Thai hot and sour soup, Korean kimchi and Indian curry [2].

Capsicum annum is one of the most essential crops grown worldwide. However, like any other crop of economic importance, chilli production is hampered by various viral diseases. Viruses that may occur on chilli include Tobacco mosaic, Cucumber mosaic, Potato Y, Tomato spotted wilt, Alfalfa mosaic, Pepper mottle, Pepper veinal mottle, Pepper ringspot and others [3-6]. Cucumber mosaic virus (CMV) has been described as one of the five most important viruses infecting vegetable species worldwide [7]. Based on a study, CMV was listed as the virus of greatest economic importance in chilli, celery, cowpea, cucrbits, lettuce and tomato [8]. This proves that $\mathrm{CMV}$ is also one of the most prevalent viruses of the chilli. Cucumber mosaic virus (CMV) is one of the most common plant viruses causing yellow molting, distorted leaves and stunted growth in a wide range of garden plants, not just cucumbers. CMV is vectored by several aphid species which feed on a broad range of plants and this contributes to the very wide host range of this virus. The 'cucumber' in its name only reflects the fact that cucumber happened to be the plant from which it was firstly described. The host range of CMV is extremely wide among vegetables, flowers and some weeds, though fruit crops are rarely attacked.

\section{MATERIAL AND METHODS}

\subsection{Sample collections and Total RNA Isolation}

\subsubsection{Material}

Healthy Capsicum annum leaves (location 1 and 2) and infected Capsicum annum leaves (location 1 and 2), liquid nitrogen, $80 \%$ Etanol, 2mercaptoethanol, Sigma-Aldrich Diethylpyrocarbonate reagent (DEPC), $0.5 \%$ Hydrogen peroxide, RNase Quiet, GF-1 Vivantis Total RNA Extraction Kit (Buffer TR, Inhibitor removal buffer, wash buffer, DNase 1 digestion mix, Fermentas RNase-free water, RNA binding columns, Homogenization columns), sterile plastics, mortars and pestles, microcentrifuge tubes, micropipettes, centrifuge, laboratory vortex.

\subsubsection{Methods}

All chilli samples were put into sterile plastics separately. The chilli samples were ground in liquid nitrogen until fine powder using a prechilled mortar and pestle. The RNA isolation was then performed according to the manufacturer's instructions.

\subsection{Reverse Transcription - Polymerase Chain Reaction}

\subsubsection{Materials}

Isolated RNA chilli samples, 5X Taq buffer, RT Enzyme Mix (RevertAid ${ }^{\mathrm{TM}}$ Premium Enzyme Mix), Taq Polymerase, 10 mM dNTP Mix, CMV Primer (Forward and Reverse), actin (Forward and Reverse), nuclease-free water, $1.5 \mathrm{~g}$ of Agarose powder, $150 \mathrm{ml}$ of TAE Buffer, SYBR® Safe DNA stain, 100 bp of DNA Ladder reagent, Blue 6 X Loading Dye, microcentrifuge tubes, PCR tubes, micropipettes and Alpha imager.

\subsubsection{Methods}

For RT-PCR analysis, two CMV primers were used for CMV gene detection sized 315 bp while two actin primers (housekeeping genes) were used for $560 \mathrm{bp}$ gene detection as an internal RT-PCR-positive control.

\begin{tabular}{|l|l|}
\hline Primer & Sequences \\
\hline CMV Primer (Forward) & 5'-AAC CTT TGT GGG TAG TGA-3' \\
\hline CMV Primer (Reverse) & 5'-TTG AAC GCC AGA TGC-3' \\
\hline $\begin{array}{l}\text { Actin (Forward) Accession no: } \\
\text { JQ256516.1 5'-TGG ACT CTG GTG ATG GTG TC-3' }\end{array}$ & \\
\hline $\begin{array}{l}\text { Actin (Reverse) Accession no: } \\
\text { JQ256516.1 5'-CCT CCA ATC CAA ACA CTG TA-3' }\end{array}$ & \\
\hline
\end{tabular}

RT-PCR was set for 50 minutes reverse-transcription at $46{ }^{\circ} \mathrm{C}$ and immediately increased the temperature to $94{ }^{\circ} \mathrm{C}$ for 2 minutes. Then, it is 
followed by denaturation for 15 seconds at $94{ }^{\circ} \mathrm{C}$. Annealing was conducted at $56{ }^{\circ} \mathrm{C}$ for 40 seconds and extension was set at $72{ }^{\circ} \mathrm{C}$ for 1 minute. The cycle was repeated for another 34 times before final extension that was done at $72{ }^{\circ} \mathrm{C}$ for 10 minutes prior incubation at $4{ }^{\circ} \mathrm{C}$.

\section{RESULTS AND DISCUSSION}

Total RNA extracted with GF-1 Vivantis Total RNA Extraction Kit was intact, and no smearing was detected (Figure 1). This shows that the isolated RNA was of high quality.

All infected plants exhibit an apparent virus-like disease symptom on the chilli leaves (from both locations; location 1: Taman pertanian Indera Mahkota; location 2: Greenhouse 12 of Horticulture Research Centre, Serdang). Based on the observations, viral disease was expressed by showing symptoms of mosaic-mottling, yellow ringspots and cholorotic leaves. Those samples are categorized as 'infected CMV chillies' while noninfected plants are classified as 'healthy chillies', and all samples were labelled according to the locations.

Actin has been used as the housekeeping gene that act as an internal standard positive control. It has been widely used as quantitative assays for the analysis of mRNA expression. Based on the result (Figure 2), expression of actin gene was constant across all samples. Clear visible bands were observed for all samples at $560 \mathrm{bp}$. The expression was also constant under changing cellular condition, such as for CMV infected leaves. However, there is no expression for non-template control (NTC) sample.

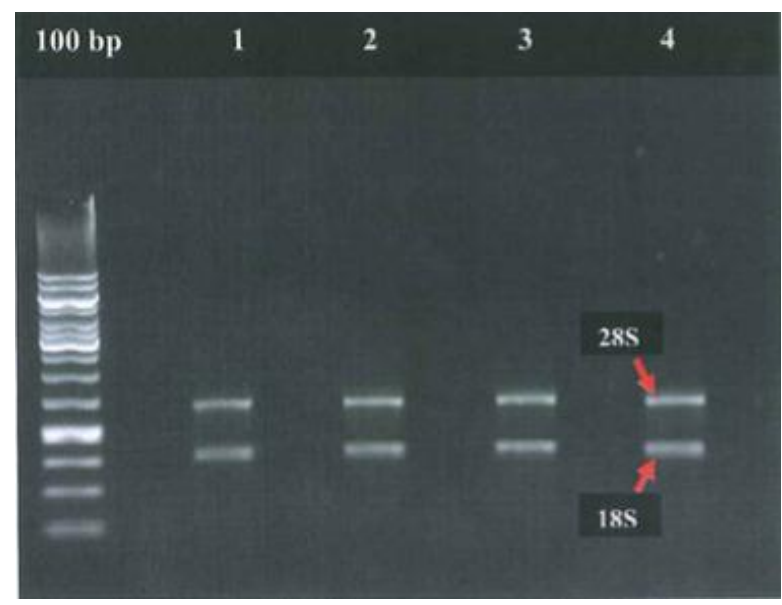

Figure 1: This figure shows isolated RNA for all samples. Lane 1: Healthy chilli (location 2); 2. CMV infected chilli (location 2); 3. Healthy chilli (location 1); 4. CMV infected chilli (location 1).

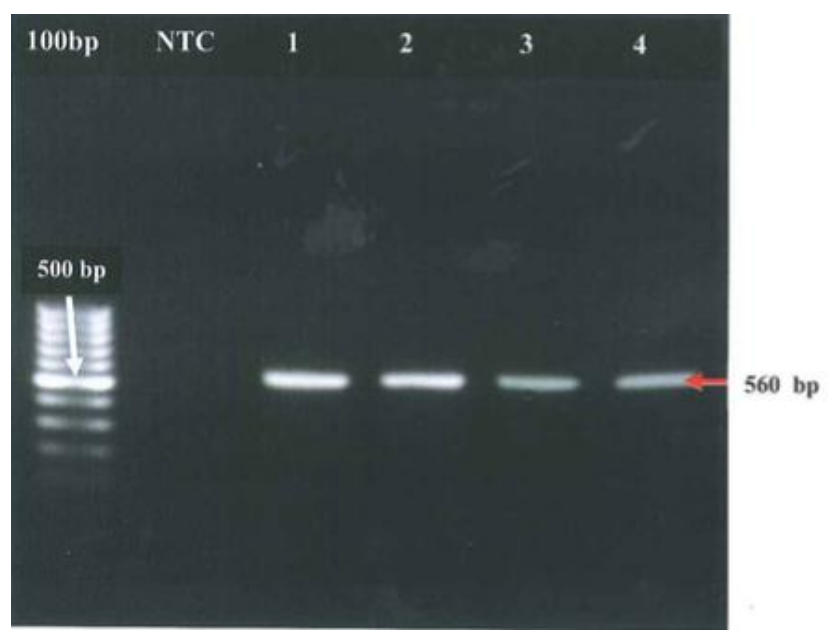

Figure 2: Figure shows actin RT-PCR products. 1. NTC: Non-template control; 1. Healthy chilli (location 2); 2. CMV infected chilli (location 2); 3. Healthy chilli (location 1); 4. CMV infected chilli (location 1).

CMV primer was used for CMV detection that primed for about approximately 315 bp DNA sequences from all symptomatic Capsicum annum plant tissues. According to the result, sample labelled (Figure 3) as 'healthy location 2' at lane 1 did not yield any visible band, while clear visible band appeared on lane 2 (CMV infected sample). Lane 3 that labelled as healthy chilli (location 1) showed no band, while on lane 4 clear band was observed. In addition, the amplification was not observed in non-template control (NTC). This showed that the "healthy chilli location 2 at lane 1 was identified as non-infected. This is expected as no CMV symptom was observed on the plant. In addition, molecular investigation confirmed that the symptomatic CMV samples which were labelled as 'CMV infected chilli location 2' in lane 2 and 'CMV infected chilli location 1' in lane 4 were infected by the CMV. The symptoms of CMV such as mosaic, mottling and chlorotic leaves proved the infection of CMV in infected.

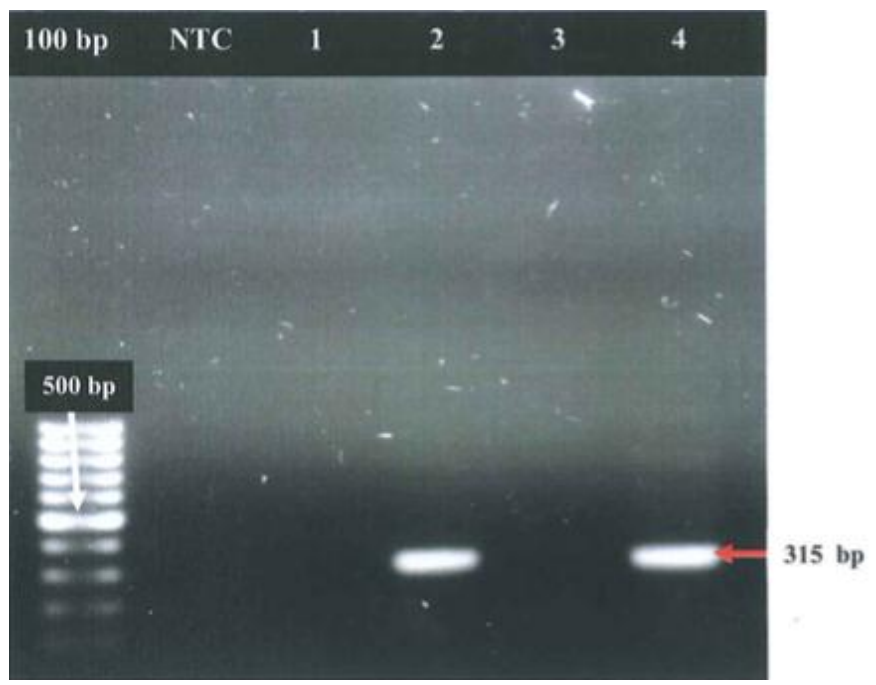

Figure 3: Figure shows CMV RT-PCR products. 1. NTC: Non-template control; 1. Healthy chilli (location 2); 2. CMV infected chilli (location 2); 3. Healthy chilli (location 1); 4. CMV infected chilli (location 1).

Based on this study, symptoms of CMV shown by a mosaic, mottling and chlorotic leaves proved the infection of CMV at infected samples as prelabelled earlier. The CMV symptoms show that the physical symptom could be correlated with the detection of the virus gene. This knowledge could be used in early detection of the infection which simultaneously could help in enhancing the protection of the crop, mainly chilli plants.

\section{CONCLUSION}

Cucumber mosaic virus is an economically importance pathogen on chilli in Malaysia. Due to the lack of commercially available resistant lines and a lack of epidemiological knowledge about the CMV population in Asia, the disease is difficult to manage. Thus, detection of CMV is important for controlling the disease. In this project, the study of the gene expression of CMV in chilli has been performed using the RT-PCR. The specific primers have targeted at the CMV coat proteins gene. The CMV gene of interest have been expressed and detected in some selected chilli plants at location 1 and location 2. It is found that the presence of CMV symptoms on the leaves is correlated with the detection of virus gene. This study also revealed that the presence of CMV can be described by its physical symptoms.

\section{ACKNOWLEDGEMENT}

International Islamic University Malaysia. Greenhouse 12 of Horticulture Research Centre, MARDI Serdang. RIGS 15-135-0135.

\section{REFERENCE}

[1] Boslan, P. W. 1996. Innovative uses of an ancient crop: In J. Janick (Ed.) of Progress in new crops. ASHS Press, Arlington, V.A., 479-487.

[2] Berke, T. 2002. The Asian vegetable research and development centre pepper project. Proceeding of the $16^{\text {th }}$ International Pepper Conference, Tampico. Tamaulipas, Mexico.

[3] Sutic, D. D., Ford, R. E., Tosic M. T. 1999. Handbook of Plant Virus Diseases. New York. CRC Press. 
[4] Hiskias, Y., Lasemann D. E., Vetten H. J. 1999. Occurrence, distribution and relative importance of viruses infecting hot pepper and tomato in the major growing areas of Ethiopia. Journal of Phytopathology, 147, 5-11.

[5] Buzkan, N., Denir, M., Oztekin, V., Mart, C., Caglar, B. K., Yilmaz, M. A. 2006. Evaluation of the status of capsicum viruses in the main growing regions of Turke. Bulletion OEPP, 36 (1), 15-19.
[6] Ryu, J. G., Ko, S. J., Lee, Y. H., Kim, M. K. Kim, K. H., Kim, H. T., Choi, H. S. 2009. Incidence and distribution of virus diseases on paprika (Capsicum annum var. grossum) in Jeonnam province of Korea. Plant Pathology Journal, 25 (1), 95-98.

[7] Palukaitis, P., Roossinck, M. J., Dietzgen, R. G., Francki, R. I. 1992. Cucumber mosaic virus. Advances in Virus Research, 41, 281-348.

[8] Gallitelli, D. 2000. The ecology of Cucumber mosaic virus and sustainable agriculture. Virus Research, 71, 9-21. 